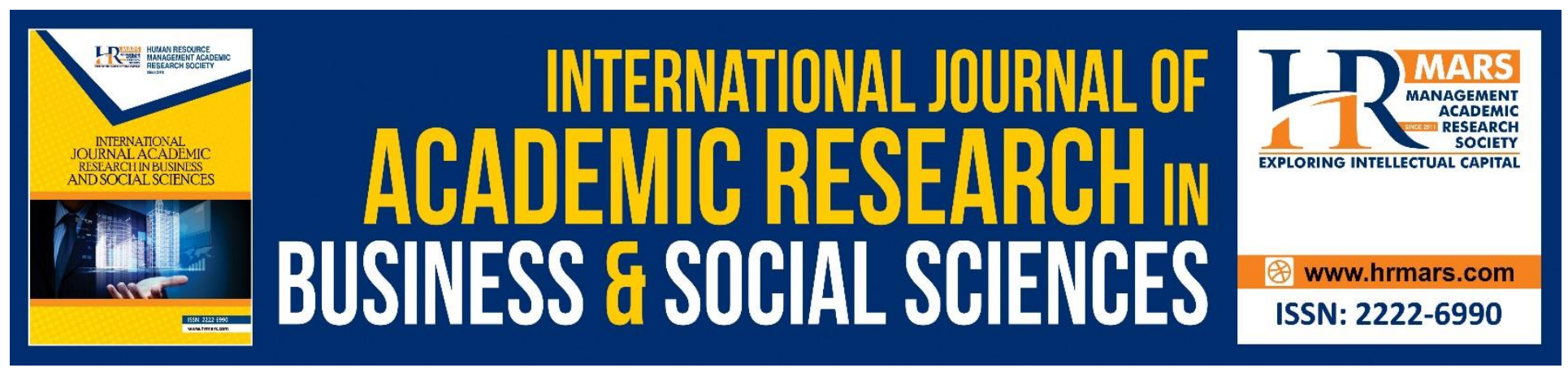

\title{
Empowering Critical Pedagogy through Forum Theatre in Teaching and Learning of Moral Education
}

Nadarajan Thambu

To Link this Article: http://dx.doi.org/10.6007/IJARBSS/v8-i11/5349

DOI: $10.6007 /$ IJARBSS/v8-i11/5349

Received: 25 Oct 2018, Revised: 21 Nov 2018, Accepted: 30 Nov 2018

Published Online: 05 Dec 2018

In-Text Citation: (Thambu, 2018)

To Cite this Article: Thambu, N. (2018). Empowering Critical Pedagogy through Forum Theatre in Teaching and Learning of Moral Education. International Journal of Academic Research in Business and Social Sciences, 8(11), 1713-1732.

Copyright: (C) 2018 The Author(s)

Published by Human Resource Management Academic Research Society (www.hrmars.com)

This article is published under the Creative Commons Attribution (CC BY 4.0) license. Anyone may reproduce, distribute, translate and create derivative works of this article (for both commercial and non-commercial purposes), subject to full attribution to the original publication and authors. The full terms of this license may be seen at: $\underline{\text { http://creativecommons.org/licences/by/4.0/legalcode }}$

Vol. 8, No. 11, 2018, Pg. 1713 - 1732

http://hrmars.com/index.php/pages/detail/IJARBSS

JOURNAL HOMEPAGE

Full Terms \& Conditions of access and use can be found at http://hrmars.com/index.php/pages/detail/publication-ethics 


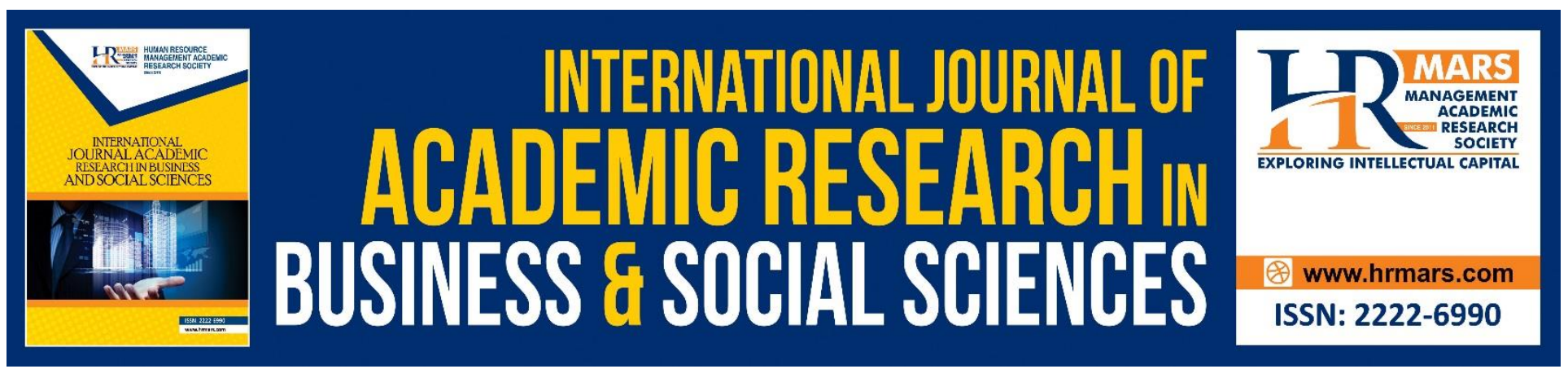

\title{
Empowering Critical Pedagogy through Forum Theatre in Teaching and Learning of Moral Education
}

\author{
Nadarajan Thambu, PhD \\ Faculty of Human Science, Sultan Idris Education University,35900, Tanjung Malim, Perak. \\ Email: nada@fsk.upsi.edu.my
}

\begin{abstract}
Implementing teaching and learning, to raising the dimension of thinking skills, team skills and moral reasoning among students, is still a major challenge to secondary school teachers. Pedagogy and classroom teaching strategies is important to stimulate students to think critically and pro-active in addressing a moral and social conflict. Furthermore, producing Malaysian citizens who are knowledgeable, creative, competent and possess high moral standards is a aspirations of Malaysian Education Blueprint 2013-2025. Conventional classroom teaching seems difficult to attract secondary school students to engage physically and mentally in moral learning process. In this regard, the use of critical pedagogy through Forum Theatre as an innovative strategies in teaching and learning of Moral Education is a current demands. Therefore, this article discusses the use and justification of critical pedagogy through Forum Theatre as 21st century pedagogy in teaching and learning of Moral Education in secondary school. The findings show that Forum Theatre technique that support philosophy and critical pedagogical features can play a role as active and interactive learning to develop students' thinking skills such as problem solving skills and team skills.
\end{abstract}

Keywords: Pedagogy, Critical Pedagogy, Moral Education, Technique, Teaching and Learning

\section{INTRODUCTION}

Moral Education (ME) is a core subject in primary and secondary education system in Malaysia. This subject is compulsory for all no-Muslim students in government and private schools (standard 1 to form 5). This subject focuses on the effort to instill spiritual and moral strength through experiential and daily virtues of Malaysian society that are found in religion, traditions, and cultural rites. A moral person, as defined in the ME program is one who abides by the Rukun Negara (National Ideology), is virtuous, is responsible, and is able to contribute towards the harmony and stability of the country and global community (Malaysia Ministry of Education, Moral Education Syllabus for Secondary School, 2000, p.v).

One of the objectives of Malaysia Education Blueprint 2013-2025 is to produce Malaysian citizens who appreciate the moral values. In this regard, the process of teaching and learning that occurs in 
the classroom, as catalyst to produce a holistic generation in terms of intellectual, spiritual, emotional and physical development (Malaysia Ministry of Education, Moral Education Syllabus for Secondary School, 2000). Research by Narvaez and Lapsley (2008) states that there is an intimate relationship between teaching practices and student character development.

The curriculum for Moral Education in Malaysia emphasizes the holistic view of students' development. Malaysian National Education Philosophy (FPK), illustrated that:

Education in Malaysia is an effort towards developing the individual's potential as a whole to foster individuals who are balanced and harmonious, intellectually, spiritually, emotionally and physically, based in belief and obeying God. This is a continuous effort to produce Malaysian citizen who are knowledgeable, dynamic, virtuous, responsible and capable of achieving self-fulfillment as well as providing their service towards the harmony and peace of the family, community and country. $\quad$ (Balakrishnan \& Claiborne, 2012, pp. 226).

In fulfilling these national educational aims, Moral Education should be concerned with educating pupils to understand, know and have the dispositions to act on values, and have the capacity to function as moral agents in the moral sphere (Chang, 2007). Morality or moral behavior is an attitude of mind occurring within a framework of beliefs and commitments. A person's duty to God, country, family or social group is the essential elements in moral behavior (Bigger \& Brown, 1999).

Teachers need to perform teaching duties effectively in a classroom environment that is arguably complex and fluid (Cohen \& Geier, 2010). Classrooms are said to have complex environments due to factors such as students, teachers and physical conditions affecting the student's learning process. The classroom environment is fluid because all the events happening inside or outside of the classroom will have an impact on the students. In this situation the teacher must play a role in implementing good teaching techniques designed to maintain student interest. Students should be given skills training and moral experience enough in the classroom, so they can learn the value and internalize it as their self habits (Balakrishnan, 2011). According to Lickona (1996),

"to develop good character they need many and varied opportunities to apply values such as responsibility and fairness in everyday interactions and discussions,..through repeated moral experiences, students can also develop and practice the moral skills and behavioural habits that make up the action side of character" (pp.96-97).

\section{PROBLEM STATEMENT}

Appropriate teaching techniques are important in the classroom because satisfaction and enjoyment in teaching depend on leading students to cooperate. Besides providing a safe and comfortable learning environment, teaching techniques can also build self esteem and motivation (Hess, 2009). The role of teachers as transmitters of values and moral content and students as passive receptors has been a teaching pedagogy of Moral Education in Malaysia (Balakrishnan, 2011). One way method of teaching and exam oriented pedagogy (Liau et al., 2003) makes the subject boring for students. Students are not interested in attending the Moral Education class (Barone, 2004). Lack of interest in this subject contributes to the unwanted behavior among school children (Barone, 2004). There is a gap between the moral syllabus and how the students approach moral conflict in their daily lives (Balakrishnan, 2011). 
In this context, the ability to communicate is an essential component for successful teaching (Roche, 2011). Research by Robinson and Lai (2006) show a normal means of communication cannot attract the student attention to focus on learning in the classroom. Conventional technique of teaching is unable to inspire them to get involved in the process of teaching and learning in the classroom. Teaching is essentially a performance (Alam Sher Malik, 2012). A performer needs to be familiar with different ways of presenting ideas and have the skill to implement them creatively. Creativity in teaching is a capacity for producing imaginative, original products or ways of solving problems (Torrance, 1983). In order to enhance this intuitive ability, teachers should explore artistic approaches, that is, approaches which focus on the facial expressions, vocal characteristic, gestures and body movements. Artistic fields of study in education such a theatre normally produce the desired response from students (Thambu, 2006).

Therefore, teachers need to explore pedagogy that can stimulate student's thinking skills and problem solving skills. The study of Pithers and Soden (2000), have proven that the thinking skills and the spirit of collaboration can be honed through collaborative learning. Furthermore, the activities of collaborative learning integrated with relevant pedagogy and technique, can function as a thinking tools to enhance the deeper knowledge. Critical pedagogy that emphasizes collaborative learning, should consider as relevant pedagogy because it is capable to be a scaffolding for the improvement of student thought and behavior. One of the creative ways to 'translate' philosophical and critical pedagogical theories in to the practice is through the Forum Theater techniques.

Meanwhile, with globalization, Malaysian youth are faced with increasing challenges in resolving social problems (Joorabchi, Mohd Salleh \& Mohd Nizam, 2013). One way of working creatively to enhance learning in the Moral Education classroom is through a technique called Forum Theatre. Forum Theatre techniques have features such as active learning and providing direct experience to students and it is a student-centered learning approach (Osburn, 2010). Artistic approaches to teaching such as Forum Theatre help students become more intuitive and adaptive in their learning (McClimens \& Scott, 2007). In this study, Forum Theatre that support philosophy and critical pedagogy's features has been used as integrated teaching and learning technique that requires students to participate actively in the process of developing a script, memorizing, engaging in forums, acting and expressing ideas. It allows students to appreciate values and think about what they are doing.

\section{CRITICAL PEDAGOGY}

Critical Pedagogy, voiced by Freire ( 1972) through his best-known work, Pedagogy of The Oppressed in Brazil. Critical pedagogy is an approach which, teachers and students are involved in learning in dealing with world reality. Critical pedagogical concepts and philosophies voiced by Freire (1972) are still on the basis of critical theories, aiming to transform a conventional education system, one-toone and autocratic teaching-learning practices and change the practice of teaching to bring social transformation to self and society ( Kincheloe, 2008). Critical Pedagogy 'refers to the process by which teachers and students negotiate and produce meaning' (McLaren, 1995, p. 34). According to McLaren 
(1998), critical pedagogy is known as "the new sociology of education" (pp. 163). Critical theory is the basis of critical pedagogy. The critical pedagogical goal is to empower students through education, and education is used as a means to create a transformation for social equality and justice for all people (McLaren, 1998). That's why Ashley and Orenstein (2001), said "critical theory is morally passionate", (p.17).

The term banking model of education was first used by Paulo Freire (1972) in his highly influential book Pedagogy of the Oppressed. Banking model of education is a term used by Paulo Freire (1972) to describe and critique the traditional education system. The name refers to the metaphor of students as containers into which educators must put knowledge. Freire (1972) argued that this model reinforces a lack of critical thinking and knowledge ownership in students, which in turn reinforces oppression, in contrast to Freire's understanding of knowledge as the result of a human, creative process.

Freire (1972) describes this form of education as "fundamentally narrative (in) character with the teacher as the subject (that is, the active participant) and the students as passive objects. Instead of communicating, the teacher issues communiqués and makes deposits which the students patiently receive, memorize, and repeat. This is the "banking" concept of education, in which the scope of action allowed to students extends only as far as receiving, filing, and storing the deposits. Education is thus seen as a process of depositing knowledge into passive students.

Banking education follows the transmission model of education. This model views education as a specific body of knowledge that is transmitted from the teacher to the student. It emphasizes teacher-centric learning where students are passive absorbers of information and that the purpose of learning is memorization of facts. The transmission model is most often used in traditional education system where teacher often play a role as a "sage of the stage".

One possible alternative to the banking model is the problem-based learning model (similar to what Freire called problem-posing education), in which students are encouraged to think and actively solve problems presented to them by the teacher. This model views the student as a person with prior knowledge that may be capitalized upon to reach greater results than a banking model that fails to take advantage of this capital. In this approach, pupils are valued as people who have full awareness and conviction to change from aspect of thinking, feeling and action. The purpose of teaching is not to guide students to memorize facts and moral content mechanically but involve them in the process of inquiry, dialogue, real life reality, conviction, knowledge, creativity, awareness and transformation in behavior (Kincheloe, 2008)

Critical pedagogy is naturally concerned with elements of dialogue. The practice of dialogue with pupils with teachers is the guiding principle of teaching (Freire, 2013). Without dialogue there is no communication and without communication the actual teaching process does not exist. Dialogue also helps and promotes the birth of positive features such as credibility, truth, creativity, courage and power in individuals (McLaren, 1998). The result is that the individual will be conscious, understand and rethink his perception of the inherent reality and administer it critically (Kincheloe, 2008). Critical pedagogy supports and recognizes the idea that students attend school with the knowledge they collect from their own life experience. The critical pedagogical goal is to use students' knowledge-experience as a bridge to create new knowledge and learning. 


\section{FORUM THEATRE}

Forum Theatre is formed from two words namely 'Forum' and 'Theatre'. Forum is derived from the Greek term meaning an open discussion field. Theatre means a genre of art or a form of communication. The goal of the Forum Theatre is to give the opportunity to the actors and the audience, to express publicly and receive views on the issues presented. This interactive theatre developed by Augusto Boal of Brazil (2008). In the Forum Theatre, the actors will dramatize social problems, or "oppression" that occurs in the community, for the community's views

(Babbage, 2004). Forum Theatre will end with an unresolved problem. Then, the audience (spectators) are given the opportunity to stage to explore solutions to the above problems through play. Forum Theatre is widely used in schools to address the issue of racism, sexual prejudice, violence, and bullying (Day, 2002).

Forum Theatre is a creative type of role play developed by a Brazilian dramatist, Boal (Rae, 2013). Forum Theatre is a form of theatre where audiences have the power to suggest and make changes to events onstage. Members of the audience are encouraged to join the action onstage, and to become co-constructors and co-actors. Viewers are given the opportunity to intervene directly in the action and to try to bring the play to a different conclusion. The role of the audience (spectators) is transformed into "spect-actors" in the Forum Theatre. Boal (2006), designated the audience-actor as "spect-actors". He further argues that the theatre is the art of looking at ourselves because all men are actors.

According to Augusto Boal (2006), Forum Theatre is not in accordance with the classical notion of theatre, a form of performance "spectacle" alone. Forum Theatre involving "dialogue" with the audience and not "one-way conversation", as is the case in conventional theatre, where intransitive relationships take over. In conventional theatre, everything moved from the stage to the auditorium. Emotions, ideas, and issues of morality and moved in that direction, none of which move toward opposite (Boal, 2006). Instead, the Forum Theatre actors not only delivered his speech, but the audience also have to answer what is seen and heard.

In Forum Theatre, gap between actors and audience have been eliminated. Audience (spectators) will change roles to become an actor (spect-actors). Spect-actors are given the opportunity to change the scene presented by assuming the role of a character is acting to bring about a change in the outcome of the story. Spect-actors will make a difference in the outcome of the story through improvisation with the ideas of other members of society (Kumpulainan \& Toom, 2009). The goal of Forum Theatre is explore clearer understanding of a social conflict that exists. In addition, the Forum Theatre also supports the goal of empowering community members to intervene in order to change the social conflicts plaguing their society (Boal, 2006). According to Augusto Boal (2006), one of the Forum Theatre motives is each person is responsible for their own actions and, when there is a problem, everyone should be involved in finding ways to solve problems. 


\section{WHY FORUM THEATRE}

Forum Theatre techniques are capable of delivering directly a series of training and moral experience in the classroom. If we go by the active learning principle, which Figure 1.1 proves that students tend to remember $90 \%$ of what is done and see if they are doing the real thing. In this approach, students was appreciated as a human being who have full awareness and consciousness to evolve in terms of thoughts, feelings and actions (Gourd \& Gourd, 2011). The purpose of teaching in Forum Theatre is not to guide students to memorise facts and moral content mechanically but to make them involve in the process of inquiry, dialogue, the reality of real life, knowledge, creativity, consciousness and transformation in behaviour (Kincheloe, 2008).

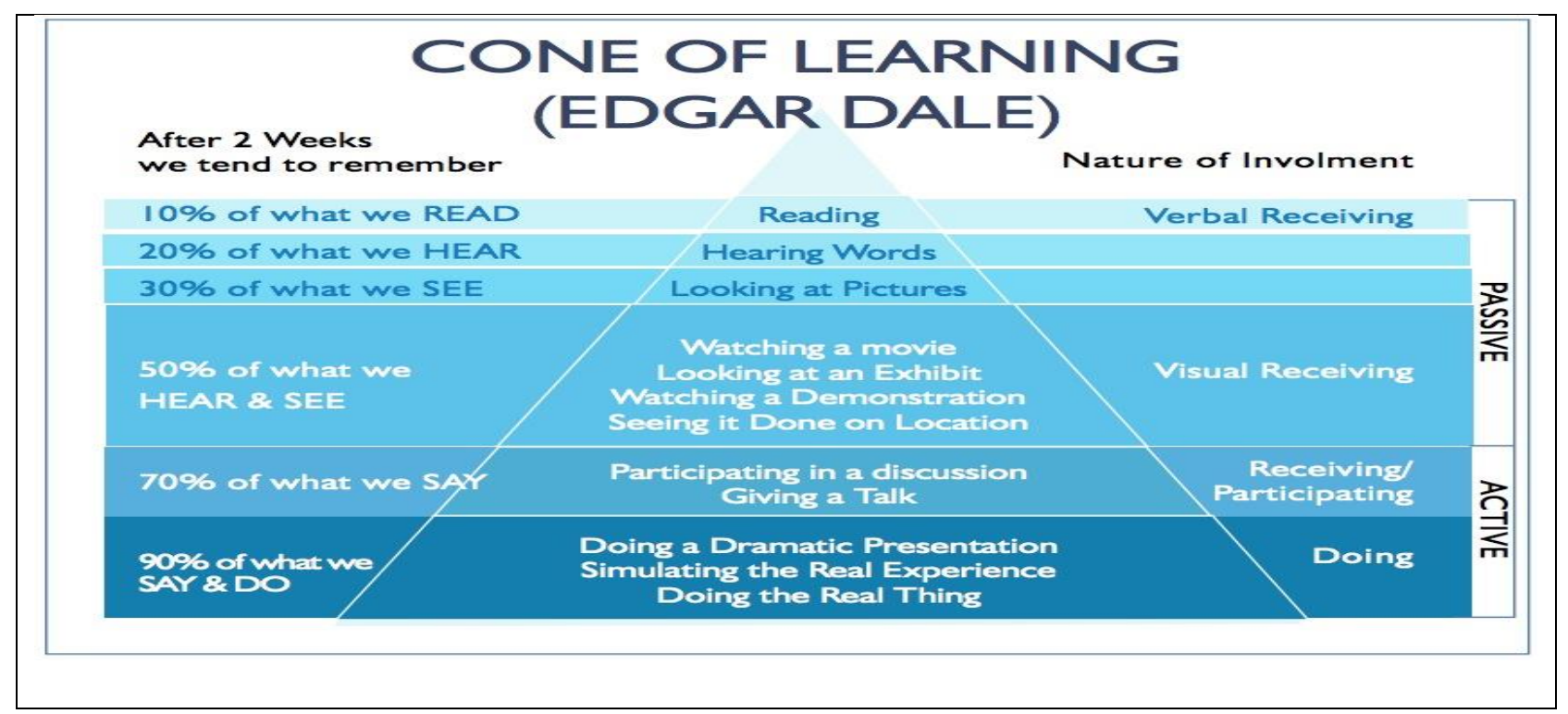

Figure: 1.1. Cone of Learning. Dale (1969).

Pedagogy is a science and art of teaching. How we teach must reflect how our students learn. It must also reflect the world our students will move into. This is a world which is rapidly changing, connected, adapting and evolving. Our style and approach to teaching must emphasize the learning in the 21st century. Even if we have a 21st Century classroom (flexible and adaptable), a 21st Century teacher (an adaptor, a communicator, a leader and a learner, a visionary and a model, a collaborator and risk taker) and our curriculum reflects the new paradigm and we have the facilities and resources that could enable 21st century learning; We will only be a 21st century teacher if we teach changes as well (Spring, 2006). Our pedagogy must also change. The key features of 21st Century Pedagogy are:

- making use of project based learning

- using problem solving as a teaching tool

- using 21st Century assessments with timely, appropriate and detailed feedback and reflection

- it is collaborative in nature and uses enabling and empowering technologies

- it fosters Contextual learning bridging the disciplines and curriculum areas

- building technological, information and media fluencies 
INTERNATIONAL JOURNAL OF ACADEMIC RESEARCH IN BUSINESS AND SOCIAL SCIENCES

Vol. 8, No. 11, Nov, 2018, E-ISSN: 2222-6990 @ 2018 HRMARS

- developing thinking skills (Refer Figure 1.2)

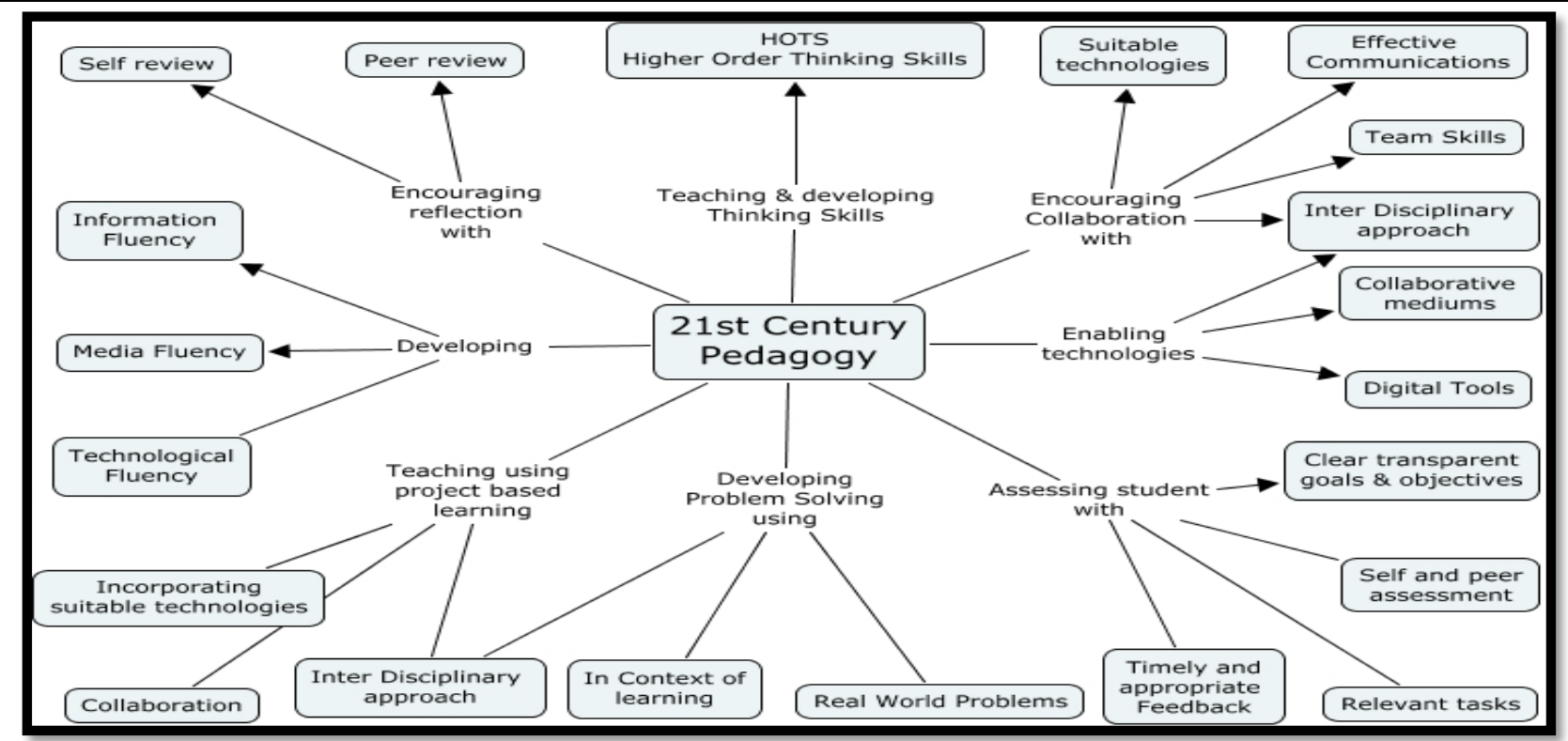

Figure 1.2: 21st Century Pedagogy. (http://www.teachthought.com).

Meanwhile, critical pedagogy through Forum Theater also meets the characteristics of 21st century pedagogy (Figure 1.2). Critical pedagogy which based on critical theory emphasize on whole human development (McLaren, 1998). The goal of critical pedagogy as a 21st century pedagogy, to produce students who can think, dialogue, make ideas, make decisions and act to solve problems before their eyes will be realized through Forum Theatre techniques.

Elements in Forum Theater such as 'develop a script' able to develop thinking skills and contextual knowledge. This steps also develop problem solving skills among students, because they use a realworld problems. While the 'anti-model play' also encourage students to work as a team, and collaborate each other. The 'forum' sessions also encourage reflection aspects such as self review and peer review. Besides that, an 'intervention play' also able to develop information fluency, and team skills. Last but not least, the use of Forum Theater in teaching moral education merger the moral discipline and theater discipline. It has realized the concept of inter-disciplinary approach in 21st century pedagogy.

\section{FORUM THEATRE AS MORAL EDUCATION PEDAGOGY}

Students were involved in four steps of Forum Theatre as recommended by Boal $(2003,2008)$. These four steps are (a) develop a script (b) anti-model play (c) forum, and (d) intervention play. The following is a discussion of how the student used them and how it worked out in the Moral Education classroom to develop students' cognitive, affective and psychomotor aspect. 


\section{Develop a Script}

In this step, students are asked to develop a script based on their own experiences of daily life. The objective of this task is to train participants to develop a script based on their own experience. In this study, the participants collaborated in developing a script about their shared challenges. In this context the focus was "moral conflict" and the scenario could be almost any topic which resonated with "oppression". Participants wrote three scripts to demonstrate the problems causing the oppressive situation. Script A related to conflicts between road users and police officers, script B involved a conflict between students and teachers in the school premises and script $C$ was about conflict between children and parents in the family.

\section{Anti-Model Play}

After composing the script, students had to act out the script developed earlier. The developed script was acted out by the students for class viewing. Their moral conflict scene was performed as an antimodel play. Although Boal (2008), gave the terms of an 'anti-model' play, we followed a different one as it was not a model we could relate to and therefore we changed it. It is compulsory for the scene (anti-model play) performed to display oppression or pressure situations, where a character being victimized fails to overcome the persecution. Thus, the issues were clarified and the students appeared to empathize with what they experienced. The original performance always ends in an unsolved form, with an undesirable challenge for the victimized character.

\section{The Forum}

After the anti-model play is completed, another step is immediately conducted by the "Joker". In Forum Theatre, the facilitator of the action is the Joker. The Joker takes responsibility for the logistics of the process and functions as a neutral link between the actors and the audience. The Joker discusses with the audience the problems that appear in the presentation and possible solutions are proposed to overcome the above problems. The Joker then asks the audience to figure out the right solution or idea that can be implemented to resolve the conflict experienced by the oppressed characters in the play. Discussion, improvisation and audience participation is known as "forum", in Forum Theatre. In our case, the appropriate solutions were discussed in a forum session by the participants.

\section{Intervention Play}

During intervention steps, the anti-model play was presented for a second time. This time the audience members have the opportunity to intervene and bring the play to a different and improved end. An audience member took the place of an actor to demonstrate his or her ideas for resolving a problem. They can do so by taking on the role of a specified victimized character from the anti-model play. When an audience member feels he or she could play the role of this character more effectively, then they shout "stop", at which point the scene of the play freezes and this audience member takes on the role, trying out alternative and desirable behavior. After that, the Joker will make sure that, the solutions are explored adequately by the audience members and that they are to some extent possible in real life. Boal (2006) wanted the audience to be active members of society, to cooperate in tackling existing conflicts in society. 


\section{METHODOLOGY}

\section{Research Design}

This study was conducted using qualitative sampling (Creswell, 2012). A purposive approach to sampling was undertaken (Richards \& Morse, 2007). Form Four science students (18 male and female of Indian and Chinese ethnicity) from three schools were selected for data collection purposes.

\section{Data Collection}

As a form of data triangulation, this study used multiple ways of obtaining qualitative data (Bogdan \& Biklen, 2007). The main method was focus group interviews, in which the selected group of students was interviewed. All interview sessions were recorded, transcribed and data were coded for analysis purposes. All transcribed verbatim reports were returned to the interviewees for them to check the accuracy of what they had said. Apart from that students' journals were used for analysis from the students' perspectives about the teaching technique and their involvement in Forum Theatre. Other sources of data such as classroom observation to investigate teachers' performance were also used.

\section{Instrument}

Instruments such as classroom observation protocol, interview protocol and journal writing method were used to collect relevant data. The content validity of the instruments was assured through comments and criticism from experts in Moral Education and Theatre Education.

Focus group interviews

Focus group interview protocol, as proposed by Creswell (2012), was used in this study to help the researchers explore, and record the data and information widely about the Forum Theatre usage in developing moral behavior. Information about the ability of Forum Theatre to develop moral practice was also collected. Focus group interviews provide an opportunity for researchers to meet face to face with their study participants, to verify the information collected through observation, and journal entries. The Interview protocol was used by the researchers to focus more on asking questions that could answer the research questions. Interviews also allow researchers to collect opinions, thoughts, insights and experiences of the study participants in the study area. In addition, the interview provided an opportunity for researchers to understand what had happened and to access thoughts by study participants about moral practice (Mohamad Nor Mohamad Taib, 2000).

\section{Observations}

Observation is a process of collecting information openly to get a true picture of the phenomena that occurs at the site of the study (Merriam 2009). Observation is the best way to collect data, about participants' behavior and is capable of collecting non-verbal data (thoughts or ideas) of participants (Creswell, 2012). Observation methods also allow researchers to move away from the perceptionbased data to data collected directly at the site (Lim, 2007). In this study, researchers used a classroom observation protocol by Seale (1999). Observations to use Forum Theatre through teaching segments that focus on the potential of this technique in developing aspects of moral practices or moral behavior have been implemented. 


\section{Journal writing}

Two forms of journal, researcher's reflective journal and student's journal, were used to obtain data. A researcher's reflection journal (Bogdan \& Biklen, 2007) was used as a written record of the observations and to express feelings, practice, experience and atmosphere experienced by the researchers in the Forum Theatre technique. The student journal (Piantanida \& Garman, 1999) was used to collect data about how their participation in Forum Theatre influenced their attitude and behavior. Journal supply data in the form of language and words (ideas recorder journal), became a rich source of information, for qualitative approach, and available for analysis without requiring any transcription (Creswell, 2012; Marohaini, 2001). Participants were also asked to record the date, events, locations and teaching sessions every time they wrote a journal entry to facilitate crossreferencing for the researcher during data analysis.

\section{Data Analysis}

The thematic approach introduced by Braun and Clarke (2006) was used for data analysis. With the thematic approach, the coding scheme was initially guided by the research questions which provided the main themes and key coding. However, the possibilities of other emerging themes that might emerge from the data were also accepted. Data from various sources and transcription codify into concepts, sub-themes and themes (Corbin \& Strauss, 2008). Data were compiled according to the order based on the breakdown of data into simple categories. Coding in qualitative research such as open coding, axial coding and selective coding is the process of identifying correlates of data into an idea, theme or category (Boeije, 2010). The inductive-deductive cycle of thinking constantly happened in our data analysis process in order to derive at the most valid codes and concepts to answer the research questions. Findings were categorized according to several themes.

\section{FINDINGS AND DISCUSSION}

\section{Interactive Learning}

Forum Theatre was able to create a highly interactive learning environment. It succeeded in creating a classroom environment that supports student learning. Students involved in four steps of Forum Theatre showed a high degree of group trust and willingness to take risks. They are engaged in learning in the classroom physically and mentally through Forum Theatre. Outcomes following interview data indicate that student participation in the conducive classroom environment.

Participant 2: In Moral we can see that we can use Forum Theatre techniques. We already see the fun antics of our friends acting ... it caught our attention. This balance varies with the normal way of teaching. In a typical drama viewer cannot give the idea in Forum Theatre we can give ideas ... and act out ideas through forums and intervention sessions. This collaboration created group cooperation. [SMKSuria/inter/5.2.13] (Author's translation).

The following is a journal entry of participants:

"All members of the group are very cooperative when it comes to training, some brought the play's prop, some are willing to buy props like a police hat and if problems arise we 
together solve the problem. All team members have the attitude and determination to write the script and acting in unity" [SMKSinar/Jour/27.2.13] (Author's translation).

Classroom observation shows participants are also having fun. They focus and concentrate while performing activities such as discussion (forums) for developing a script, writing a script, participating in an anti-model play and intervention play.

In the meantime, some of the participants commented that the Forum Theatre:

Participant 3: "It's ... it ... stimulate students enjoy ... easy ... but we must have a lot of guts ... and creative .... Teacher must give a lot of time for us to be ready ... then... ok ... if all of us work together then easy for us to create a play. Acting is interesting... and we quickly understand what is shown. We'll really see and hear, the anti-model play takes place in front of our eyes the acting is lively so we can understand better" [SMKCahaya/inter/22.2.13] (translated version).

In the journal entry, participants noted that:

"It is fun. We are not stress ... no tension now .... if not before ..... many say Moral is boring subjects ... as we always write notes .. notes.. and memorize the values .... if students do not memorize the moral standing to class exhausted ... for shame ... that's why many of us skip Moral Education class. Now when there are activities such as anti- model play, intervention and theater games, it's more fun, reduce stress" [SMKSinar/jour/7.3.13] (Author's translation).

\section{Facilitates Active Learning}

Forum Theatre is also able to facilitate experience based or active learning. This finding is consistent with previous studies that indicate the effectiveness and value of involving students in their learning experience through experience and simulation (Boggs, Mickel, \& Holtom, 2007). Chickering and Gamson (1987) described experiential learning as a best practice for students. They emphasized the process which makes learning is meaningful. According to Chickering and Gamson (1987), "learning is not a spectator sport...(students) must talk about what they are learning, write about it, relate it to past experiences, and apply it to their daily lives"(p. iii). Our key teachings in moral education required attitude shifts of our students. Direct experience and first hand exploration which students gain from Forum Theatre activity seemed to be the best way to get there.

Participants declare in a journal entry that:

"We get experience in acting ... and the experience of being in a situation that we are playing ...and this facilitates quickly makes us recalls all the values we are played

We have the experience to find the values that correspond to the situation.... and try out in the intervention play.... We belief we can use the same method to solve problems in real life" [SMKSinar/jour/7.3.13] (Author's translation). 
Classroom observation shows that among the key aspects identified through experiential learning is an aspect of creativity and leadership among students. Students are very creative in writing stories together. They are able to write creatively daily experiences encountered by them in the form of an interesting acting script. In one scenario (script B), for example, students are able to show the conflict faced by students and teachers in the school premises well. Conflicts such as one involving a sports teacher who is unaware of student problems, attitudes that do not comply with the classroom rules, the teacher's negligence while on duty and the problems in friendship can be described by the antimodel play for the students [SMKSinar/obser/26.2.13].

Participants were also creative in describing the atmosphere of tension existing between the students and teachers at the school field and in the counseling room well. Researchers felt that the class was energized by the experience and the creative product were "owned" by all the participants.

Participant5: "Forum Theatre makes us think ... think out of the box ...and be creative.

Students show creativity as we write scripts, write dialogue ... we also have to have the imagination to pretend to be the teacher counselor, teacher ... Man ... and other characters. .... And ... We also need to be creative while acting in intervention play to find an idea, create a role-playing situation, to resolve existing problems and to draw the attention of the audience "[SMKCahaya/inter/12.4.13] (Author's translation).

\section{Team Skills}

Forum Theatre activity stimulates co-learning or cooperative learning among participants. Students greatly enjoyed the activities and researchers noted a very high level of participation from all the students in the classroom. The process of acting in an anti-model play or an intervention play prompted laughter and some competition among students. This element of Forum Theatre stimulated participation from all class members. Group members helped each other to solve the problem addressed by the other group through anti-model play. Each group of students generated rich and significant content about their own experiences to create a solution for the problem through intervention play. A deeper understanding of course material was achieved, along with a wealth of connections such as students to material and students to each other [SMKCahaya/obser/8.3.13].

This is evidenced by the following interview:

Participant 5: "If you use Forum Theatre in the Moral Education subject is good.. more nice, because there is no stress. It will create a 'critical thinking' ... students can cooperate .... and the relationship between teacher and pupil better .... because there is cooperation...and studying is fun" [SMKCahaya/inter/12.4.13].

Researcher: How Forum Theatre create critical thinking? 
INTERNATIONAL JOURNAL OF ACADEMIC RESEARCH IN BUSINESS AND SOCIAL SCIENCES

Vol. 8, No. 11, Nov, 2018, E-ISSN: 2222-6990 @ 2018 HRMARS

Participant 6: "When we compose the script .. we compose it creatively..... while acting in anti- model play..we ... also include a ' sense of humor' ... think of how we can get students' attention ... well ... how to act..." [SMKSinar/inter/24.1.13] (Author's translation).

This conclusion is supported by the following excerpts:

Participant 1: "Every group member was chip in the idea... All of us discuss together before create the script...the script is our own self-authored script ... We prepare the props ourselves".

Participant2: "Acting.... even our own ... we train on our own after school hours ... 20 minutes every day... usually we use school hall for training every day ... Sometimes we

like to watch a YouTube to find a way to act" [SMKSuria/inter/9.4.13] (Author's translation).

Participant journal entries show that Forum Theatre helps them speak in a more bold and confident way:

"Yes, ..confident.. use expressions like ..... well .. let say if we attend our scholarship interview..we have to speak with confidence and courage ... we need to use good expression ... acting" [SMKSuria/jour/9.4.13] (Author's translation).

Mutual help or aid was clearly seen in how the participants carried out the process of composing and typing scripts, preparing costumes and lending equipment such as laptop computers, finding the props, providing a scenario, correcting the style of acting partners as required fictional character, making-up and helping a friend in dressing. Participants preferred the interest of the group (teamwork) to achieve planned goals in the classroom.

Refer to the following interview:

Participant3: "More fun to learn moral in this way...we now ... more than happy with moral are activities that involve all of us, it's more interesting and fun ... Other than that, now we are on good terms with all our classmates.. we respect each other ... we also respect the self-esteem of our friends ...we will not fight and hurt our friends feeling" [SMKSinar/inter/28.2.13] (Author's translation).

\section{Thinking Skills}

According to observers, practices such as trying hard and not easily giving up hope are, shown by participants. Participants said they were willing to act together with their friends even though many could not easily lead the character given to them. While many still relied on the scripts written down (rather than memorizing the script) they still acted with confidence and kept acting in the anti-model play to the end. Their attitude and their confidence levels were also good and they were not even 
INTERNATIONAL JOURNAL OF ACADEMIC RESEARCH IN BUSINESS AND SOCIAL SCIENCES

Vol. 8, No. 11, Nov, 2018, E-ISSN: 2222-6990 (C) 2018 HRMARS

bothered with cheers and shouts of the spectator. Participants were confident in the ability of themselves. [Surya/Obr/yoka/26.2.13]

Meantime, observations also show that the group has been criticized by the actors (spect-actors) for not enact anti-model play very well. However, according to observers participants can show a good performance and to convince the audience in the intervention play. Participants have a strong selfendurance to continue a difficult task. [Sinar/Inter/Ros/5.3.13]

Analysis of observation findings are supported by interviews with participants. Participants believe an attitude of trust motivated them to act or do a job or an assignment.

Participant 2: After teacher demonstrated to us how to be in the theatre and the way the play must perform, we bit confident. We believe and can act well. We realize if we do not believe in making this, we must not be made ... today we all believe in acting. [Sinar/Inter/009/28. 2.13]

Participant 4: Forum Theatre makes us more rational and give us problem-solving skills. Various events such as writing the script and acting actually increase our self-confidence to do the work. We believe in acting and we act in front of the class. We realize everyone else can act in front of the class. [Suria /Inter/010/12. 3.13]

The journal entries indicate the success of their roles and their first attempt has reinforced the confidence of participants. They did not give up hope. Failure to do the first turn was regarded as the driving force to continue to work harder to solve a given problem. Furthermore, participants' journal entries also confirmed their competent practice. They acknowledged that the positive praise also create confidence in the abilities of the participants themselves. They could carry out their assignment without any fear.

After our success of group was praised by friends and teacher Nada, I believe in acting of intervention play once again. I'm more confident when teacher Nada supported us with playing a brother character in our play. [Sinar/Jur/ R3/6.3.13]

I can do the best with the confidence because there is a motivation from teacher Nada. I have tried to act with courage and confidence. [Suria/Jur/R4/ 9.4.13]

I'm satisfied with my acting in intervention play. Before the play I'm confident that I can do well and I believe that I can do, to make sure our success. [Cahaya /Jur /R5/ 4/11/13]

Analysis of the source of findings showed that all participants believed in their own ability. In addition, moral support from friends and teachers also encouraged good practice. Self-confidence in the ability to solve problems was also obvious amongst them. 


\section{CONCLUSION}

In this article, the authors provided readers with some framework for the principles and practices of Critical Pedagogy through Forum Theatre in a Moral Education classroom setting. Therefore, the proposal of this study to use Forum Theater techniques as a Moral Education pedagogue is actually rooted in critical pedagogy (Freire, 1972). The concept of dialogue, education in the form of problemsolving (problem-posing) method of reflection, and full conviction in critical pedagogy has been implemented by Boal (2008) through Forum Theatre technique. The Forum Theater emphasizes dialogue between actors and dialogues in the form of forums; expressing real-world issues through scripted scripts from life experiences as well as raising awareness to participants through anti-model play and intervention play. The philosophy of transformation proposed by Freire (1972) in critical pedagogy and individual awareness and change by Boal (2008) is in line with the philosophy of Moral Education which aims to produce Malaysians who are able to achieve their well-being and can contribute towards the harmony of nations and the global community.

\section{Acknowledgement}

We wish to acknowledge the Ministry of Higher Education, Malaysia, Research Management \& Innovation Centre (RMIC) and Faculty of Human Science, Sultan Idris Education University [File No: 2016-0159-106-01] for the research grant enabling this study to be carried out.

\section{Corresponding Author}

Nadarajan Thambu

Faculty of Human Science, Sultan Idris Education University,35900, Tanjung Malim, Perak.

Email:nada@fsk.upsi.edu.my

\section{References}

Malik, A.S. (2012, May 27). Teaching is a performing art: Enliven the lesson at all its stages. New Sunday Times, p. 25.

Ashley, D., \& Orenstein, D.M. (2001). Sociological theory: Classical statement (5th ed.). Boston: Allyn \& Bacon.

Babbage, F. (2004). Augusto Boal. New York, NY: Routledge.

Barone, T. (2004). Moral dimension of teacher-student interactions in Malaysian secondary schools. Journal of Moral Education, 33(2), 179-196.

Bigger, S., \& Brown, E. (Ed.). (1999). Spiritual, moral, social and cultural education: Exploring values in the curriculum. London: David Fulton Publishers.

Boal, A. (2006). The aesthetics of the oppressed. Oxford: Routledge. 
INTERNATIONAL JOURNAL OF ACADEMIC RESEARCH IN BUSINESS AND SOCIAL SCIENCES

Vol. 8, No. 11, Nov, 2018, E-ISSN: 2222-6990 (C) 2018 HRMARS

Boal, A. (2008). Theatre of the oppressed (new edition). London, UK: Pluto Press.

Boeije, H. (2010). Analysis in qualitative research. Thousand Oaks, CA: Sage.

Bogdan, R. C., \& Biklen, S. K. (2007). Qualitative research for education: An introduction to theories and methods. New York, NY: Pearson.

Boggs, J. G., Mickel, A. E., \& Holtom, B. C. (2007). Experiential learning through interactive drama: An alternative to student role-plays. Journal of Management Education, 31(6), 832-858.

Braun, V., \& Clarke, V. (2006). Using thematic analysis in psychology. Qualitative Research psychology, 3(2), 77-101.

Chang, L. H. (June, 2007). Moral reasoning of Malaysian adolescents. Paper presented at the International Conference on Learning, Johannesburg, South Africa.

Chickering, A., \& Gamson, Z. (1987). Seven principles for good practice in undergraduate education. Wingspread Journal. Winona, MN: Winona State University.

Cohen, J., \& Geier, V. (2010). School climate research summary. School Climate Brief, 1. New York, NY: National School Climate Centre. Retrieved from www.schoolclimate.org/climate/research.php

Corbin, J., \& Strauss, A. (2008). Basics of qualitative research (3rd Ed.).Thousand Oaks: Sage.

Creswell, J. W. (2012). Educational research: Planning, conducting, and evaluation quantitative and qualitative research (4th ed.). Englewood Cliffs, NJ: Pearson.

Dale, E. (1969). Audio-Visual methods in teaching (3rd ed.). New York, NY: Holt, Rinehart \& Winston.

Day, L. (2002). Putting yourself in other people's shoes: The use of forum theatre to explore refugee and homeless issues in schools. Journal of Moral Education, 31(1), 21-34.

Freire, P. (1972). Pedagogy of the oppressed. Great Britain: Penguin Books.

Gourd, K. M., \& Gourd, T. Y. (2011). Enacting democracy: Using Forum Theatre to confront bullying. Equity \& Excellence in Education, 44(3), 403-419.

Hess, D. E. (2009). Controversy in the classroom: The democratic power of discussion. New York, NY: Routledge. 
INTERNATIONAL JOURNAL OF ACADEMIC RESEARCH IN BUSINESS AND SOCIAL SCIENCES

Vol. 8, No. 11, Nov, 2018, E-ISSN: 2222-6990 (C) 2018 HRMARS

Joorabchi, T. N., Md. Salleh Hj. Hassan., \& Mohd. Nizam Osman. (2013). Relationship between internet usage and positive youth development in Malaysia. Search: The Journal of the South East Asia Research Centre for Communication and the Humanities, 5(2), 37-64.

Kincheloe, J. (2008). Knowledge and critical pedagogy: An introduction. Amsterdam, The Netherlands: Springer.

Kumpulainan, K. , \& Toom, A. (eds). (2009). ETEN 18:Proceedings of the 18th Annual Conference of the European Teacher Education Network. Helsinki, Finland: Department of Applied Sciences of Education and Cicero Learning, University of Helsinki.

Retrieved from http://www.etenonline.org/img/publications/ETEN_Proceedings_18.pdf

Liau, A. K., Liau, A. W. L., Teoh, G. B. S., \& Liau, M. T. L. (2003). The case for emotional literacy: The influence of emotional intelligence on problem behaviours in Malaysian secondary school students. Journal of Moral Education, 32(1), 51-66.

Lickona, T. (1996). Eleven principles of effective character education. Journal of Education, 25(1), 93-100.

Lim, C. H. (2007). Penyelidikan pendidikan: Pendekatan kuantitatif dan kualitatif. Shah Alam: McGraw-Hill.

Malaysia Ministry of Education (MOE). (2000). Moral Education Syllabus for secondary school Malaysia. Kuala Lumpur: Curriculum Development Centre.

Marohaini Yusoff. (2001). Penyelidikan kualitatif: Pengalaman kerja lapangan kajian. Kuala Lumpur: Penerbit Universiti Malaya.

McClimens, A., \& Scott, R. (2007).Lights, camera, education! The potentials of forum theatre in a learning disability nursing program. Nurse Education Today, 27(3), 203-209.

McLaren, P. (1995). Critical pedagogy and predatory culture: Oppositional Politics in a postmodern era. New York, NY: Routledge.

McLaren, P. (1998). Life in schools: An introduction to critical pedagogy in the foundations of education (4th ed.). Boston, MA: Allyn \& Bacon.

Merriam, S. B. (2009). Qualitative research: A guide to design and implementation. San Francisco: Jossey-Bass. 
INTERNATIONAL JOURNAL OF ACADEMIC RESEARCH IN BUSINESS AND SOCIAL SCIENCES

Vol. 8, No. 11, Nov, 2018, E-ISSN: 2222-6990 (C) 2018 HRMARS

Taib, M.N.M. (2000). Model guru sebagai penyelidik: Asas-asas menjalankan kajian di sekolah. Kuala Lumpur: Bahagian Perancangan dan Penyelidikan Dasar Pendidikan.

Thambu, N. (2006). Penggunaan teknik drama di dalam kelas Pendidikan Moral tingkatan IV. Unpublished Master's Dissertations, University Malaya, Kuala Lumpur.

Narvaez, D., \&. Lapsley, D. K. (eds). (2008). Moral Personality, Identity, and Character: An Interdisciplinary Future. Cambridge, UK: Cambridge University Press.

Osburn, K. M. (2010). Forum Theatre Empowering Students to speak, Act and Know. Unpublished Bachelor's Dissertations, Western Kentucky University. Retrieved from http://digitalcommons.wku.edu/stu_hon_theses/245

Piantanida, M., \& Garman, N. B. (1999). A qualitative dissertation: A guide for students and faculty. Thousand Oaks: Sage.

Pithers, R. T., \& Soden, R. (2000). Critical Thinking in education: A review. Educational Research, 42(3), 237-249.

Rae, J. (2013). Facilitating learning spaces in forum theatre. European Journal of Training and Development, 37(2), 220-236.

Richards, L., \& Morse, J. M. (2007). Readme first for a user's guide to qualitative methods. London: Sage.

Robinson, V. M., \& Lai, M. K. (2006). Practitioner research for educators: A guide to improving classroom and schools. Thousand Oaks, CA: Corwin Press.

Roche, M. (2011). Creating a dialogical and critical classroom: Reflection and action to improve practice. Educational Action Research, 19(3), 327-343.

Seale, C. (1999). The quality of qualitative research. London, UK: The Falmer Press.

Spring, J. (2006). Pedagogies of globalization: The rise of the educational security state. Mahwah, New Jersey: Lawrence Erlbaum Associates, Publishers.

Torrance, E. P. (1983). Creativity in the classroom. Washington, DC: Library of Congress.

Balakrishnan, V. (2011). Real-life dilemmas in moral education. Kuala Lumpur: University of Malaya Press.

Balakrishnan,V., \& Claiborne, L.B. (2012). Vygotsky from ZPD to ZCD in moral education: 
INTERNATIONAL JOURNAL OF ACADEMIC RESEARCH IN BUSINESS AND SOCIAL SCIENCES

Vol. 8, No. 11, Nov, 2018, E-ISSN: 2222-6990 @ 2018 HRMARS

reshaping Western theory and practices in local context. Journal of Moral Education, 41(2), 225-243. 